\title{
Combining Agronomic and Pest Studies to Identify Vegetable Soybean Genotypes Suitable for Commercial Edamame Production in the Mid-Atlantic U.S.
}

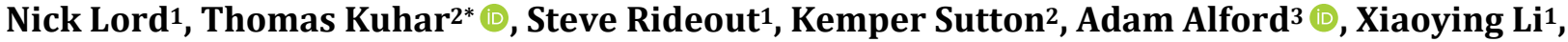 \\ Xingbo Wu ${ }^{1}$, Mark Reiter ${ }^{\circledR} \odot$, Helene Doughty ${ }^{4}$, Bo Zhang $1 \oplus$ \\ ${ }^{1}$ School of Plant and Environmental Sciences, Virginia Tech, Blacksburg, VA, USA \\ ${ }^{2}$ Department of Entomology, Virginia Tech, Blacksburg, VA, USA \\ ${ }^{3}$ Department of Agriculture, Culinology and Hospitality Management, Southwest Minnesota State University, Marshall, MN, USA \\ ${ }^{4}$ Virginia Tech Eastern Shore Agricultural Research and Extension Center, Painter, VA, USA \\ Email: ^tkuhar@vt.edu
}

How to cite this paper: Lord, N., Kuhar, T., Rideout, S., Sutton, K., Alford, A., Li, X.Y., Wu, X.B., Reiter, M., Doughty, H. and Zhang, B. (2021) Combining Agronomic and Pest Studies to Identify Vegetable Soybean Genotypes Suitable for Commercial Edamame Production in the Mid-Atlantic U.S. Agricultural Sciences, 12, 738-754.

https://doi.org/10.4236/as.2021.127048

Received: June 20, 2021

Accepted: July 17, 2021

Published: July 20, 2021

Copyright $\odot 2021$ by author(s) and Scientific Research Publishing Inc. This work is licensed under the Creative Commons Attribution International License (CC BY 4.0).

http://creativecommons.org/licenses/by/4.0/ (c) (i) Open Access

\begin{abstract}
Currently, domestic production of vegetable soybean (aka "edamame") lags well behind consumer demand, with approximately $70 \%$ of U.S.-consumed edamame imported each year. A major barrier for growth of the U.S. edamame industry is an overall lack of varieties with adequate consumer acceptability and adaption to the U.S. climate and environment. In this study, we evaluated eleven vegetable soybean genotypes (including one commercial check) for differences in yield, pod size, and resistance to local insect, bacterial, and fungal pressures in order to identify genotypes with the greatest potential for use in commercial edamame production. Although there were variations in average pod length (42.1 - $53.6 \mathrm{~mm})$, width $(10.9-12.7 \mathrm{~mm})$, and thickness $(6.29-7.34 \mathrm{~mm})$ among the genotypes, only pod length showed statistical significance. In addition, genotype significantly affected fresh pod yield. The prevalence of specific insect pests varied by location and year and included soybean aphid, potato leafhopper, Mexican bean beetle, as well as a complex of stink bugs and lepidopteran larvae. For each of these insect pests, significant differences were observed. Some plant diseases observed on the edamame genotypes included: downy mildew, bacterial pustule, Fusarium pod rot, Cercospora blight and purple seed stain, and damping off. In 2018, in Whitethorne, VA, soybean downy mildew was quite prevalent and disease symptoms varied considerably. Overall, genotypes V16-0524 and R15-10280 showed particularly favorable yield, and resilience to native pests compared to the
\end{abstract}


commercial check, UA-Kirksey. The genotypes V16-0524 and R15-10280 showed strong potential to increase the availability of varieties that can be used for commercial edamame production in the Mid-Atlantic region.

\section{Keywords}

Edamame, Genotypes, Pests, Agronomics, Breeding

\section{Introduction}

Edamame, or immature soybean (Glycine max [L.] Merr.), has been a popular food in East Asia for centuries [1] [2], and is growing in popularity in the United States with around 25,000 to 30,000 tons annual consumption. The name edamame is Japanese for "stem beans" because the crop has often been marketed with the pods still on the stems [3]. Since it was first introduced to U.S. markets two decades ago, edamame has become a fixture in many sushi restaurants and salad bars nationwide and inspired many edamame or edamame-infused food products in the domestic marketplace such as freeze-dried snacks, edamame pasta, and dry roasted edamame. Frozen edamame pods or shelled beans are also available to consumers in grocery stores year-round, which has led to increased consumption of edamame at home.

Given its unique nutritional profile, edamame is an ideal candidate to help the western world meet dietary guidelines recommended by the USDA. Fresh edamame beans contain $10 \%$ to $14 \%$ protein and are rich in essential amino acids, dietary fiber, minerals, and vitamins [4]. Studies have shown that edamame contains 50\% more protein than garden peas ( $P$. sativum) [5], and thus could be a better choice for people seeking a low fat, high protein food source [6]. Edamame, as a type of soybean, also contains isoflavones that have been associated with a number of potential health benefits in the human body, including increased antioxidant activity [7], cancer prevention [8], and a reduction of "bad" LDL cholesterol which contributes to cardiovascular disease [9]. This has distinguished edamame as a functional food source capable of providing consumers with many additional benefits beyond basic nutritional requirements.

The increasing availability of edamame as various commercial foods speaks for its emerging acceptance and popularity among U.S. consumers. However, with roughly $70 \%$ of edamame products consumed annually in the U.S. still being imported from overseas, U.S. growers have been largely unable to capitalize on this opportunity. The lack of domestic adoption can be attributed to many factors, primarily related to edamame's relative novelty in the U.S. Such factors include general uncertainty regarding economic potential, chemical regulations, and best management practices as well as a scarcity of commercial processing facilities. In addition, the majority of edamame varieties available to growers are introduced from other countries and expensive. Very few edamame varieties have 
been bred specifically for major production regions and consequently lack the yield or pest resistance to be used for commercial production [10].

In Virginia specifically, several studies have been conducted to address many of these aforementioned barriers. While there are no commercial processing facilities in the Mid-Atlantic region of the U.S. for growers to access the frozen market, a recent Virginia Tech feasibility study suggested that machine-harvested, fresh market edamame can be both a feasible and profitable enterprise for growers [11]. Strong consumer interest and high potential price premiums for fresh and locally marketed edamame were observed during a willingness to pay study conducted in Southwest Virginia (Lord, et al., unpublished data). With one of the more diverse agricultural portfolios in the country, Virginia soybean and green or snap bean producers may already be in position to add edamame into their crop rotation. This leaves development of commercially viable and pest tolerant edamame varieties as one of the final remaining market needs necessary to permit commercial production in the state and region.

From an agronomic standpoint, edamame varieties must maintain high emergence rates and fresh weight pod yield as well as tolerance to local pests and diseases [12] [13] [14]. From a marketing standpoint, large bean size (>250 mg) and pod dimensions of fresh pods are particularly important for appearance and consumer acceptance [4] [15]. Edamame pods should be considerably longer, wider, and thicker than pods of conventional grain-type soybean [16] [17]. Personal communication with commercial bean growers has also indicated that for edamame, a low pubescence density (visible hairs on the pod) is preferred to make pods appear more appetizing and to reduce water accumulation on the surface of the pods following the hydro-cooling process in commercial packing houses. Lastly, to further increase profitability for producers, edamame variety development must also target reduced occurrence of pods containing a single bean, which are not generally marketable unless shelled [18].

Decades of soybean breeding in the U.S. for grain production with little interest in edamame production has resulted in limited genetic resources for breeders and edamame improvement [19]. Nevertheless, many food-grade soybean genotypes developed for tofu and soymilk possess characteristics and seed compositional traits that are essential for edamame, such as large seed size, higher sucrose, reduced antinutrient content, non-GMO designation, and enhanced digestibility. There has been a particularly long-standing focus on food-grade soybean variety development at both Virginia Tech and the University of Arkansas. In this study, we sought to evaluate the potential of food-grade soybean genotypes from both breeding programs for commercial edamame production. To do this, we collected information on bean yield, pod dimensions, and frequency of one-bean pods from 10 large-seeded soybean genotypes and one commercial variety, UA-Kirksey, to identify genotypes with the most favorable agronomic and consumer acceptance characteristics [20]. We also collected data on local pest and disease pressures and how they affected each genotype in the field in order 
to more holistically understand the agronomic performance of each genotype. All of the aforementioned data were analyzed over two years and two locations to identify strong candidate genotypes for edamame production in the Mid-Atlantic U.S.

\section{Materials \& Methods}

\subsection{Description of Plant Materials}

After a preliminary screening of twenty-three conventional genotypes to eliminate genotypes with either poor agronomic performance or bad bean appearance, ten prospective edamame genotypes and one commercial check were evaluated in this study (Table 1). The prospective edamame genotypes consisted of

Table 1. $f$-values, $d f$, $p$-values, and broad-sense heritability $\left(H^{2}\right)$ from the two-way ANOVA testing the treatment effect of genotype on various agronomic and pest variables among edamame genotypes evaluated in Virginia.

\begin{tabular}{|c|c|c|c|c|c|}
\hline Dependent variable & Location* (year) & $f$-value & $d f$ & $p$-value & $H^{2}$ \\
\hline Pod length & W \& P pooled (2018 \& 2019) & 2.499 & 10,117 & 0.009 & 0.918 \\
\hline Pod width & W \& P pooled (2018 \& 2019) & 1.432 & 10,117 & 0.174 & 0.899 \\
\hline Pod thickness & W \& P pooled (2018 \& 2019) & 0.559 & 10,117 & 0.845 & $\mathrm{NC}$ \\
\hline Pod pubescence & W (2019) & 10.379 & 1044 & 0.0001 & $\mathrm{NC}$ \\
\hline 10-pod weight & W \& P pooled (2018 \& 2019) & 3.628 & 10,117 & 0.0001 & 0.731 \\
\hline $\begin{array}{l}\text { Proportion of pods } \\
\text { with only one seed }\end{array}$ & W \& P pooled $(2018 \& 2019$ & 2.040 & 10,117 & 0.0003 & 0.858 \\
\hline Fresh pod yield & W \& P pooled (2019) & 2.286 & 1065 & 0.0001 & 0.824 \\
\hline Soybean aphid & W (2018) & 0.872 & 1030 & 0.5686 & - \\
\hline Soybean aphid & P (2018) & 3.484 & 1030 & 0.0308 & - \\
\hline Soybean aphid & P (2019) & 2.735 & 1030 & 0.0161 & - \\
\hline Potato leafhopper & P (2018) & 0.491 & 1030 & 0.8615 & - \\
\hline Potato leafhopper & $\mathrm{P}(2019)$ & 3.364 & 1030 & 0.0048 & - \\
\hline Potato leafhopper & W (2019) & 1.971 & 1030 & 0.0737 & - \\
\hline Mexican bean beetle & W (2018) & 0.669 & 1030 & 0.7433 & - \\
\hline Mexican bean beetle & W (2019) & 7.581 & 1030 & 0.0001 & - \\
\hline Lepidopteran larvae & $P(2018)$ & 0.558 & 1030 & 0.8140 & - \\
\hline Lepidopteran larvae & W (2018) & 0.543 & 1030 & 0.8456 & - \\
\hline Lepidopteran larvae & P (2019) & 0.661 & 1030 & 0.7507 & - \\
\hline Chewing pod damage & P (2019) & 2.397 & 1030 & 0.0314 & - \\
\hline Stink bug seed damage & P (2019) & 1.881 & 1030 & 0.0883 & - \\
\hline Stink bug seed damage & W (2019) & 7.772 & 1030 & 0.0001 & - \\
\hline Downy mildew & W (2018) & 22.943 & 1030 & 0.0001 & - \\
\hline Bacterial blight & P (2019) & 2.013 & 1030 & 0.0236 & - \\
\hline Diseased pods & P (2019) & 10.649 & 1030 & 0.0001 & - \\
\hline
\end{tabular}

${ }^{\star}$ Locations: $\mathrm{W}=$ Whitethorne, $\mathrm{VA}, \mathrm{P}=$ Painter, VA 
ten large-seeded, food-grade soybean breeding lines initially developed in Arkansas or Virginia for tofu and soymilk end-use. UA Kirksey [21], a major commercial edamame variety grown in the Mid-South region of the U.S., was included as a commercial check (standard). All genotypes in the study, including the commercial check, belonged to maturity group V.

\subsection{Field Plots}

All ten genotypes and the commercial check were evaluated at Virginia Tech's Kentland Farm in Whitethorne, VA and the Eastern Shore Agricultural Research and Extension Center in Painter, VA in 2018 and 2019. Experimental plots were arranged in a randomized complete block design with four replications with the exception of Painter in 2018, which had two replications. Experimental units were one row plots at Whitethorne and two row plots in Painter. Painter had two row plots so that the second row could serve as seed increase. Plots in Whitethorne were $0.75 \mathrm{~m}$ row spacing and $5.5 \mathrm{~m}$ long. Plots in Painter were $0.91 \mathrm{~m}$ row spacing and $6.1 \mathrm{~m}$ long. Plots were machine planted with a cone type soybean planter in May at a seeding rate of 20 seeds $/ \mathrm{m}$. Two pre-emergent herbicides, metalochlor (Dual Magnum, Syngenta Crop Protection) at $0.21 \mathrm{~kg}$ a.i./ha and chloransulam-methyl (First Rate, AMVAC Chemical Corp.) at $44.1 \mathrm{~g}$ a.i./ha were applied prior to planting. Preplant fertilizer was applied to plots if required based on soil test results. In Whitethorne, plots were entirely rainfed; no irrigation was made prior to or during planting. However, in Painter, irrigation occurred during dry periods from planting until the R4 growth stage.

\subsection{Data Collection}

\subsubsection{Harvest and Pod Assessment}

Edamame plots were hand-harvested during September and October of each year when most seeds of each genotype had fully expanded in the pods at the R6 growth stage [22]. Pod dimensions, seed size, and proportion of one-seeded pods were all defined before the crop reached the R6 stage, and these traits remained constant until maturity [23]. Therefore, in order to determine suitability for commercial production, assessment of these traits was performed at the R6 or "green bean" stage when the immature seeds reach $80 \%$ to $90 \%$ pod capacity. For harvest, plants were cut at the base of their stems and placed in large garbage bags to prevent sample mixing. The edamame pods were then immediately handpicked directly from bundles to ensure quality and minimize damage. The mass of all pods per 3-m of row was recorded as $\mathrm{kg} / \mathrm{ha}$. Pod traits including pod width $(\mathrm{mm})$, pod length $(\mathrm{mm})$, pod thickness $(\mathrm{mm})$, number of one-bean pods, and 10-pod weight $(\mathrm{g})$ were then evaluated. For pod dimensions, 10 fresh pods were randomly selected and measured for their length, width, and thickness $(\mathrm{mm})$. The number of pods with one bean in each 10-pod subsample was recorded to determine the proportion of one-bean pods. 10-pod weight was averaged from the weight of 50 fresh pods. All the fresh pods were collected and 
weighed immediately for fresh pod weight (kilograms) and assessment of the number of single-bean pods.

\subsubsection{Pubescence}

A subsample of 10 pods per plot was assessed for pubescence using a dissecting microscope (Nikon Model SNZ-1270, Tokyo, Japan). The numbers of hairs visible per $2.4 \mathrm{~cm}^{2}$ section in the middle of the pod was recorded. This area was used as it was found to be an optimal field of view under magnification for clear visibility of the pod hairs.

\subsubsection{Sampling Insect Pests}

In both years, edamame genotypes were surveyed weekly per plot and any economically-important insect pests were recorded. Based on previous research in Virginia common pests include: soybean aphid, Aphis glycines Matsumura, potato leafhopper Empoasca fabae (Harris), Mexican bean beetle, Epilachna varivestis Mulsant, stink bugs (Euschistus spp., Chinavia hilaris (Say), and Halyomorpha halys (Stål), and corn earworm Helicoverpa zea Boddie [24] [25] [26] [27]. Weekly surveys occurred by visual inspection of five plants per plot from 4-leaf until the R1 growth stage. From R2 to R6, two-minute visual sampling of the entire plot occurred. Because of their abundance, soybean aphids were assessed on five leaves per plot per week. Cumulative weekly counts of the most predominant insect pests were used for analysis.

At harvest, insect damage to pods was categorized as chewing (holes) or stink bug. Chewing damage was recorded by visually assessing the exterior of the pods for any holes or scars, while stink bug feeding could only be recorded by opening the pod and observing the beans directly for feeding marks and undeveloped damaged seeds [25] [27].

\subsubsection{Sampling Foliar and Pod Diseases}

Foliar pathogens, such as bacterial blight and downy mildew, were assessed when present (downy mildew at Whitethorne in 2018 and bacterial blight at Painter in 2019). For both diseases, incidence and severity ratings were taken periodically throughout the growing season. In addition, edamame pods were assessed for disease at harvest by collecting 50 random pods per plot. Individual pods were assessed for symptoms and signs of disease infection, those showing damage were deemed unmarketable. Unmarketable pods were counted, weighed and grouped based on symptomology present. Diseased pods were grouped based on symptomology and pods were disinfected using $0.6 \% \mathrm{NaOCl}$ for 1.5 minutes. Infected tissues from a representative pod of each symptom were cut from the disease margin and plated on acidified potato dextrose agar (APDA) to determine which pathogens were present based on treatment/plot number.

\subsection{Statistical Analysis}

Based on a randomized complete block design, two-way analysis of variance 
(ANOVA) was performed using PROC GLM in JMP version 14.0 (SAS Institute Inc., Cary, NC). When possible, data were analyzed with year and location as variables, but because not all variables were collected at all locations and years or because there was insufficient replication at some locations, some variables were either pooled when appropriate and when there was no significant interaction, or analyzed for specific locations and years only (Table 1). Edamame genotype and block were considered fixed effects, and means for plot yield, pod dimensions, 10-pod sample weights, proportion one-seeded pods, pod pubescence, cumulative densities of major insect pests (including aphids, leafhoppers, Mexican bean beetles, lepidopteran larvae, and stink bugs) as well as the proportion of insect-damaged pods or diseased pods were separated by Fisher's LSD when significant $(p<0.05)$ or highly significant $(p<0.01)$ differences were found. Prior to analysis, for each of the major pest species encountered, season total cumulative insects were calculated by multiplying the mean densities of two successive sample dates by the sampling interval (days), and totaling the insects for successive sample dates.

\section{Results}

\subsection{Agronomic Characteristics}

\subsubsection{Pod Dimensions}

Edamame pod length ranged from 40 to $51 \mathrm{~mm}$ among the varieties. There was a highly significant effect of genotype on pod length (Table 1), with most of the Arkansas (R) genotypes and the commercial standard UA-Kirksey having generally longer pods (47 to $51 \mathrm{~mm}$ ) than most of the Virginia (V) genotypes (40 to $46 \mathrm{~mm}$; Table 2). However, there was no significant effect of genotype in pod width or thickness (Table 1). Pod widths were quite similar ranging from $10.86 \pm$ 0.24 to $12.16 \pm 0.43 \mathrm{~mm}$ (Table 2). Pod thickness ranged from $6.47 \pm 0.19$ to $8.14 \pm 0.86 \mathrm{~mm}$ among the genotypes.

\subsubsection{Pubescence}

There was a highly significant effect of genotype in pod pubescence (Table 1). The genotypes with the highest density of hairs on pods included R14-6283, V16-0528, R14-16195, and V16-0547; whereas, R15-10280, V16-0524, and R07589 had the fewest hairs and significantly fewer than UA-Kirksey (Table 2).

\subsubsection{0-Pod Characteristics and Yield}

10-pod sample weights (in grams) were pulled across locations and years to assess a robust sample. There was a highly significant effect of genotype in the average weight of ten pods (Table 1 ). The heaviest pods were found in the genotypes R14-6450 and R15-10280 (Table 3). One of the reasons for a lower pod weight was fewer seeds. There was a significant effect of genotype on the proportion of one-seeded pods (Table 1), with some of the genotypes such as R165336, V10-3653, and V16-0547 having twice as high of a proportion one-seeded pods as other genotypes like R14-6450 and UA-Kirksey (Table 3). 
Table 2. Pod dimensions and pubescence of potential edamame genotypes from Arkansas and Virginia compared with a commercial standard variety, UA-Kirksey, grown in Whitethorne, VA and Painter, VA in 2018 and 2019.

\begin{tabular}{ccccc}
\hline \multirow{2}{*}{ Genotype } & \multicolumn{3}{c}{ Mean \pm SEM $(\mathrm{mm})$} & Pod pubescence \\
\cline { 2 - 4 } & Length & Width & Thickness & (hairs per 2.4 $\left.\mathrm{cm}^{2}\right)$ \\
\hline R07-589 & $42.3 \pm 1.9 \mathrm{~cd}$ & $11.1 \pm 0.3$ & $6.9 \pm 0.7$ & $422.6 \pm 49.3 \mathrm{fg}$ \\
R14-6238 & $47.6 \pm 2.2 \mathrm{abc}$ & $11.3 \pm 0.4$ & $7.0 \pm 0.8$ & $1096.0 \pm 97.1 \mathrm{a}$ \\
R14-6450 & $50.3 \pm 2.9 \mathrm{a}$ & $12.2 \pm 0.4$ & $7.2 \pm 0.8$ & $629.4 \pm 63.7 \mathrm{def}$ \\
R14-16195 & $43.1 \pm 2.2 \mathrm{bcd}$ & $12.1 \pm 0.4$ & $7.8 \pm 0.8$ & $869.0 \pm 136.6 \mathrm{bc}$ \\
R15-10280 & $47.5 \pm 2.7 \mathrm{abc}$ & $12.0 \pm 0.4$ & $8.1 \pm 0.9$ & $340.8 \pm 43.3 \mathrm{~g}$ \\
R16-5336 & $48.8 \pm 1.9 \mathrm{ab}$ & $11.6 \pm 0.3$ & $6.5 \pm 0.2$ & $607.6 \pm 43.8 \mathrm{def}$ \\
UA-Kirksey & $47.8 \pm 1.7 \mathrm{abc}$ & $11.5 \pm 0.4$ & $7.2 \pm 0.4$ & $699.6 \pm 32.7 \mathrm{cde}$ \\
V10-3653 & $45.7 \pm 1.1 \mathrm{abcd}$ & $11.7 \pm 0.3$ & $7.0 \pm 0.3$ & $553.0 \pm 33.0 \mathrm{efg}$ \\
V16-0524 & $40.4 \pm 1.8 \mathrm{~d}$ & $11.4 \pm 0.3$ & $7.6 \pm 0.7$ & $359.0 \pm 22.8 \mathrm{~g}$ \\
V16-0528 & $42.2 \pm 1.8 \mathrm{~cd}$ & $10.9 \pm 0.2$ & $7.4 \pm 0.3$ & $984.2 \pm 133.3 \mathrm{ab}$ \\
V16-0547 & $42.5 \pm 2.2 \mathrm{~cd}$ & $12.0 \pm 0.3$ & $7.9 \pm 0.6$ & $819.0 \pm 88.0 \mathrm{bcd}$ \\
p $<$ & 0.0090 & NS & NS & 0.0001 \\
\hline
\end{tabular}

Numbers within a columns followed by the same letter are not significantly different according to Fisher's LSD at alpha $=0.05$.

Table 3. Fresh pod yield (LS Means), 10-pod sample weights, and proportion of oneseeded pods (mean \pm SEM) of potential edamame genotypes from Arkansas and Virginia compared with a commercial standard variety, UA-Kirksey.

\begin{tabular}{cccc}
\hline Genotype & $\begin{array}{c}\text { Fresh pod wt at harvest (kg } \\
\text { per ha) }\end{array}$ & $\begin{array}{c}\text { 10-pod sample wt } \\
\text { (grams) }\end{array}$ & $\begin{array}{c}\text { Proportion one-seeded } \\
\text { pods }\end{array}$ \\
\hline R07-589 & $12,977.2 \pm 1429.2 \mathrm{c}$ & $13.1 \pm 0.5 \mathrm{bc}$ & $0.17 \pm 0.04 \mathrm{bc}$ \\
R14-6238 & $17,964.4 \pm 1378.6 \mathrm{a}$ & $12.9 \pm 1.0 \mathrm{c}$ & $0.22 \pm 0.05 \mathrm{ab}$ \\
R14-6450 & $18,324.8 \pm 1289.5 \mathrm{a}$ & $16.4 \pm 0.6 \mathrm{a}$ & $0.10 \pm 0.03 \mathrm{c}$ \\
R14-16195 & $14,747.3 \pm 208.5 \mathrm{bc}$ & $14.1 \pm 1.0 \mathrm{bc}$ & $0.18 \pm 0.03 \mathrm{bc}$ \\
R15-10280 & $16,898.5 \pm 2042.7 \mathrm{ab}$ & $16.4 \pm 0.7 \mathrm{a}$ & $0.19 \pm 0.03 \mathrm{abc}$ \\
R16-5336 & $15,509.0 \pm 1244.6 \mathrm{abc}$ & $12.8 \pm 0.9 \mathrm{c}$ & $0.22 \pm 0.03 \mathrm{ab}$ \\
UA-Kirksey & $17,706.9 \pm 529.2 \mathrm{ab}$ & $14.1 \pm 0.5 \mathrm{bc}$ & $0.11 \pm 0.03 \mathrm{c}$ \\
V10-3653 & $15,553.6 \pm 1308.9 \mathrm{abc}$ & $13.3 \pm 0.6 \mathrm{bc}$ & $0.29 \pm 0.05 \mathrm{a}$ \\
V16-0524 & $18,110.9 \pm 2230.3 \mathrm{ab}$ & $13.9 \pm 0.5 \mathrm{bc}$ & $0.15 \pm 0.04 \mathrm{bc}$ \\
V16-0528 & $15,639.8 \pm 1030.7 \mathrm{abc}$ & $13.1 \pm 0.6 \mathrm{c}$ & $0.19 \pm 0.05 \mathrm{abc}$ \\
V16-0547 & $17,683.0 \pm 2539.2 \mathrm{ab}$ & $15.0 \pm 0.4 \mathrm{ab}$ & $0.22 \pm 0.04 \mathrm{ab}$ \\
p $<$ & 0.0229 & 0.0003 & 0.0351 \\
\hline
\end{tabular}

Numbers within a columns followed by the same letter are not significantly different according to Fisher's LSD at alpha $=0.05$.

Because of lack of replication and significant vertebrate (deer) grazing damage to the edamame plots in 2018, yield was not analyzed, but was recorded and analyzed from the two Virginia sites in 2019. Because there was no significant 
interaction between variety and location in yield $(\mathrm{F}=0.8017 ; \mathrm{df}=10.65 ; \mathrm{p}=$ 0.6275), data were pooled across the two locations to assess the main effect of genotype, which was significant (Table 1). The four highest yielding genotypes were statistically the same as the commercial standard variety (UA Kirksey) and included R14-6238, V16-0524, R14-6450, and V16-0547 (Table 3).

\subsubsection{Broad-Sense Heritability}

Broad-sense heritability was calculated for all agronomic traits with the exception of pubescence and pod thickness due to missing data. Analysis was conducted under a genotype-environment framework, where the year-location combination was treated as a random sample in the population of the target environment in order to view year-location combinations as a single environment. Broadsense heritability $\left(\mathrm{H}^{2}\right)$ of pod length and width was approximately 0.918 and 0.899 , respectively. $\mathrm{H}^{2}$ of 10 -pod weight was 0.731 , while $\mathrm{H}^{2}$ of yield and proportion of one-bean pods was 0.824 and 0.858 , respectively (Table 1 ).

\subsubsection{Correlation between Agronomic Traits}

Pearson's correlation coefficient $(r)$ and probability $(p)$ values of t-test were performed by the R statistical package (version 4.0.2, https://www.r-project.org/) in order to assess correlations between agronomic traits. The results showed that pod length was negatively correlated $(\mathrm{p}<0.01)$ with both pod width and pod thickness. Pod width was positively correlated $(\mathrm{p}<0.01)$ with pod thickness $(\mathrm{r}=$ $0.63)$ and bean weight $(r=0.63)$. All of pod width, thickness, and bean weight were positively correlated $(\mathrm{p}<0.01)$ with one bean proportion, while pod weight and yield were negatively correlated $(\mathrm{p}<0.01)$ with one bean proportion. Yield was not significantly correlated with other traits involved in this work. Results for correlations between agronomic traits can be seen in Table 4 .

Table 4. The correlation coefficient among fresh edamame traits.

\begin{tabular}{|c|c|c|c|c|c|c|c|}
\hline $\begin{array}{l}\text { Edamame } \\
\text { Traits }\end{array}$ & $\begin{array}{c}\text { Pod } \\
\text { Length } \\
(\mathrm{mm})\end{array}$ & $\begin{array}{c}\text { Pod } \\
\text { Width } \\
(\mathrm{mm})\end{array}$ & $\begin{array}{c}\text { Pod } \\
\text { Thickness } \\
(\mathrm{mm})\end{array}$ & $\begin{array}{c}10 \text { Pod } \\
\text { Weight (g) }\end{array}$ & $\begin{array}{c}20 \text { Bean } \\
\text { Weight (g) }\end{array}$ & $\begin{array}{c}\text { Yield } \\
(\mathrm{Mg} / \mathrm{ha})\end{array}$ & $\begin{array}{c}\text { Proportion } 1 \\
\text { bean }\end{array}$ \\
\hline $\begin{array}{l}\text { Pod Length } \\
\qquad(\mathrm{mm})\end{array}$ & NA & $-0.27^{\star *}$ & $-0.43^{* *}$ & 0.00 & $-0.55^{\star *}$ & 0.00 & $-0.26^{*}$ \\
\hline $\begin{array}{l}\text { Pod Width } \\
\qquad(\mathrm{mm})\end{array}$ & NA & NA & $0.63^{* *}$ & $0.21^{*}$ & $0.63^{* *}$ & -0.01 & $0.31^{* *}$ \\
\hline $\begin{array}{l}\text { Pod Thickness } \\
\qquad(\mathrm{mm})\end{array}$ & NA & NA & NA & $-0.30^{* *}$ & $0.47^{* *}$ & -0.04 & 0.15 \\
\hline $\begin{array}{c}10 \text { Pod } \\
\text { Weight (g) }\end{array}$ & NA & NA & NA & NA & $0.31^{*}$ & 0.10 & $-0.20^{*}$ \\
\hline $\begin{array}{c}20 \text { Bean } \\
\text { Weight }(\mathrm{g})\end{array}$ & NA & NA & NA & NA & NA & 0.07 & $0.65^{\star *}$ \\
\hline Yield (Mg/ha) & NA & NA & $\mathrm{NA}$ & NA & NA & NA & -0.10 \\
\hline $\begin{array}{l}\text { Proportion } 1 \\
\text { bean }\end{array}$ & NA & NA & NA & NA & NA & NA & NA \\
\hline
\end{tabular}

Note: ${ }^{*}$ Indicates that the correlation is significant at $\mathrm{p}<0.01$, and ${ }^{*}$ indicates that the correlation is significant at $\mathrm{p}<0.05$. 


\subsection{Pests}

\subsubsection{Insects}

Soybean aphid, Aphis glycines Matsumura, was an abundant pest at both Virginia locations in 2018 and in Painter in 2019. This invasive pest of soybean is native to Asia, but became established in the U.S. in 2000 [28]. Although there was no significant effect of genotype on cumulative densities (recorded as aphid days) at Whitethorne in 2018 (Table 1), there was a significant genotype effect on aphids in Painter in both 2018 and 2019 (Table 1). In both years at Painter, the highest cumulative aphid densities were observed on R14-6238, V10-3653, V16-0524, V16-0528, and R16-5336; whereas, R07-589, V16-0547, and particularly, R15-10280 (220.5 \pm 225.6 in $2018,44.0 \pm 19.4$ in 2019), had fewer aphids (Table 5).

Potato leafhopper occurred in moderate densities in both years in Painter and in 2019 in Whitethorne. There was no significant effect of genotype on cumulative leafhoppers in 2018 in Painter, but there was in 2019 at that location (Table 1), with V16-0547, R07-589, R15-10280, and UA-Kirksey having the fewest numbers of leafhoppers (Table 4). Although there were no statistically significant differences between counts of potato leafhoppers in Whitethorne in 2019, the numeric trends were similar to those observed in Painter, with V16-0547 having the fewest leafhoppers at both locations (Table 5).

Mexican bean beetle was only present in notable numbers at the Whitethorne

Table 5. Cumulative insects (mean \pm SEM) for two hemipteran leaf-sucking pests, soybean aphids and potato leafhoppers, sampled weekly on edamame genotypes from Arkansas and Virginia and a commercial standard variety, UA-Kirksey, grown in two locations of Virginia in 2018 and $2019^{1}$.

\begin{tabular}{ccccc}
\hline & \multicolumn{2}{c}{$\begin{array}{c}\text { Cumulative soybean aphids } \\
\text { per five leaves }\end{array}$} & $\begin{array}{c}\text { Cumulative potato leafhopper nymphs } \\
\text { per five plants }\end{array}$ \\
\hline Genotype & Painter, VA 2018 & Painter, VA 2019 & Whitethorne, VA 2019 & Painter, VA 2019 \\
\hline R07-589 & $378.0 \pm 152.1 \mathrm{de}$ & $112.0 \pm 41.1 \mathrm{~cd}$ & $85.9 \pm 23.0$ & $74.3 \pm 13.0 \mathrm{de}$ \\
R14-6238 & $1596.0 \pm 57.9 \mathrm{a}$ & $304.0 \pm 55.2 \mathrm{a}$ & $97.5 \pm 39.0$ & $162.4 \pm 32.8 \mathrm{a}$ \\
R14-6450 & $717.5 \pm 334.4 \mathrm{bcde}$ & $96.0 \pm 30.2 \mathrm{~cd}$ & $166.3 \pm 17.1$ & $142.1 \pm 28.0 \mathrm{abc}$ \\
R14-16195 & $644.0 \pm 131.1 \mathrm{de}$ & $142.0 \pm 10.9 \mathrm{bcd}$ & $97.5 \pm 20.7$ & $153.0 \pm 18.0 \mathrm{ab}$ \\
R15-10280 & $220.5 \pm 225.6 \mathrm{e}$ & $44.0 \pm 19.4 \mathrm{~d}$ & $70.2 \pm 13.7$ & $84.4 \pm 12.1 \mathrm{de}$ \\
R16-5336 & $987.0 \pm 386.9 \mathrm{abcd}$ & $182.0 \pm 46.0 \mathrm{abc}$ & $81.9 \pm 26.6$ & $126.4 \pm 20.9 \mathrm{abcd}$ \\
UA-Kirksey & $661.5 \pm 267.6 \mathrm{cde}$ & $261.0 \pm 87.1 \mathrm{ab}$ & $127.3 \pm 41.2$ & $70.1 \pm 6.1 \mathrm{e}$ \\
V10-3653 & $1438.5 \pm 64.6 \mathrm{ab}$ & $226.0 \pm 38.3 \mathrm{abc}$ & $62.0 \pm 20.9$ & $90.8 \pm 19.1 \mathrm{cde}$ \\
V16-0524 & $1407.0 \pm 285.1 \mathrm{abc}$ & $181.0 \pm 30.3 \mathrm{abc}$ & $84.2 \pm 9.1$ & $106.5 \pm 7.2 \mathrm{bcde}$ \\
V16-0528 & $938.0 \pm 190.9 \mathrm{abcde}$ & $184.0 \pm 19.4 \mathrm{abc}$ & $53.5 \pm 9.6$ & $104.6 \pm 15.5 \mathrm{bcde}$ \\
V16-0547 & $623.0 \pm 155.9 \mathrm{de}$ & $127.0 \pm 48.0 \mathrm{~cd}$ & $41.7 \pm 15.6$ & $57.4 \pm 8.8 \mathrm{e}$
\end{tabular}

${ }^{1}$ Only data where the insect pest occurred in significant numbers are shown in the table. Numbers within a column followed by the same letter are not significantly different according to Fisher's LSD at $\mathrm{p}<0.05$. 
location. There was no significant effect of genotype on cumulative densities of that pest in 2018, but there was a highly significant effect in 2019 (Table 1) caused primarily by the susceptibility of the Arkansas genotypes, R14-6238, R14-6450, R14-16195, and R15-10280 relative to other varieties in the study (Table $6)$.

Densities of lepidopteran larvae on edamame were generally low and were comprised of a mix of species primarily including green cloverworm, Hypena Scabra Fabr., corn earworm, and soybean looper, Chrysodeixis includens (Walker). Because of the low densities, all lepidopteran larvae were pooled together for assessment. There was no significant effect of genotype on cumulative lepidopteran larval numbers in 2018 in Painter or Whitethorne, or in Painter in 2019 (Table 1). At Whitethorne in 2019, densities of lepidopteran larvae were so low that data were not analyzed.

Lepidopteran larvae, as well as Mexican bean beetles, can chew holes in edamame pods resulting in direct damage to the marketable product. This variable was minimal $(<5 \%)$ in both years and locations; however, in 2019 in Painter, there was a significant effect of genotype on chewing insect pod damage (Table 1) with the two Arkansas genotypes, R14-6450 and R14-16195 having the most chewing damage (Table 6).

Table 6. Cumulative insects (mean \pm SEM) of Mexican bean beetles observed weekly for 2-minutes and chewing or stink bug feeding pod damage at harvest on edamame genotypes from Arkansas and Virginia and a commercial standard variety, UA-Kirksey, grown in two locations of Virginia in 2018 and $2019^{1}$.

\begin{tabular}{ccccc}
\hline & $\begin{array}{c}\text { Cumulative Mexican } \\
\text { bean beetles per } \\
\text { 2-min visual sample }\end{array}$ & \multicolumn{2}{c}{$\begin{array}{c}\text { \% of pods with chewing } \\
\text { insect damage }\end{array}$} & $\begin{array}{c}\text { \% of pods with stink } \\
\text { bug feeding injury }\end{array}$ \\
\hline Genotype & $\begin{array}{c}\text { Whitethorne, } \\
\text { VA 2019 }\end{array}$ & $\begin{array}{c}\text { Painter, VA } \\
2019\end{array}$ & $\begin{array}{c}\text { Whitethorne, } \\
\text { VA 2019 }\end{array}$ & $\begin{array}{c}\text { Whitethorne, } \\
\text { VA 2019 }\end{array}$ \\
\hline R07-589 & $325.5 \pm 26.8 \mathrm{bcd}$ & $2.5 \pm 1.3 \mathrm{ab}$ & $3.5 \pm 1.8$ & $4.0 \pm 0.8 \mathrm{c}$ \\
R14-6238 & $451.4 \pm 86.8 \mathrm{ab}$ & $1.0 \pm 0.5 \mathrm{~b}$ & $2.5 \pm 1.9$ & $6.0 \pm 1.9 \mathrm{bc}$ \\
R14-6450 & $459.0 \pm 54.0 \mathrm{ab}$ & $4.5 \pm 1.9 \mathrm{a}$ & $6.5 \pm 3.1$ & $1.5 \pm 1.5 \mathrm{c}$ \\
R14-16195 & $567.8 \pm 39.0 \mathrm{a}$ & $4.5 \pm 0.8 \mathrm{a}$ & $1.5 \pm 1.6$ & $1.0 \pm 1.6 \mathrm{c}$ \\
R15-10280 & $556.8 \pm 28.3 \mathrm{a}$ & $1.0 \pm 0.3 \mathrm{~b}$ & $4.5 \pm 0.4 \mathrm{bc}$ & $6.5 \pm 1.3 \mathrm{bc}$ \\
R16-5336 & $262.6 \pm 9.5 \mathrm{~cd}$ & $0.5 \pm 0.2 \mathrm{~b}$ & $2.5 \pm 1.4$ & $3.0 \pm 1.1 \mathrm{c}$ \\
UA-Kirksey & $360.9 \pm 35.1 \mathrm{bc}$ & $1.0 \pm 0.9 \mathrm{~b}$ & $1.5 \pm 1.0$ & $6.0 \pm 4.3 \mathrm{bc}$ \\
V10-3653 & $282.0 \pm 59.2 \mathrm{~cd}$ & $2.0 \pm 0.4 \mathrm{ab}$ & $4.0 \pm 1.8$ & $20.0 \pm 4.9 \mathrm{a}$ \\
V16-0524 & $328.8 \pm 30.3 \mathrm{bcd}$ & $0.0 \pm 0.3 \mathrm{~b}$ & $2.0 \pm 1.6$ & $0.0 \pm 1.1 \mathrm{c}$ \\
V16-0528 & $222.5 \pm 43.9 \mathrm{~d}$ & $1.5 \pm 0.5 \mathrm{~b}$ & $3.0 \pm 1.0$ & $12.0 \pm 2.9 \mathrm{~b}$ \\
V16-0547 & $195.2 \pm 20.6 \mathrm{~d}$ & $2.0 \pm 1.3 \mathrm{ab}$ & $3.0 \pm 1.1$ & $20.5 \pm 1.9 \mathrm{a}$ \\
p $<$ & 0.0001 & 0.0314 & 0.7004 & 0.0001
\end{tabular}

${ }^{1}$ Only data where the insect pest occurred in significant numbers are shown in the table. Numbers within a column followed by the same letter are not significantly different according to Fisher's LSD at $\mathrm{p}<0.05$. 
A complex of stink bugs including Euschistus servus Say, C. hilaris, and $H$. halys (Pentatomidae) occurred on the edamame during pod fill and fed upon the seeds through the pod husks. This injury showed up as malformed seeds or full seeds with conspicuous marks after shelling. This injury was recorded in 2019 only. In Painter, the percentage of pods with stink bug injured seeds averaged between $17.5 \%$ to $34.0 \%$ and there was no significant effect of genotype (Table 1). In Whitethorne in 2019, genotype had a highly significant effect on stink bug injury (Table 1). Genotypes that had the least amount of stink bug injury included V16-0524, R07-589, R14-6450, R14-16195, R16-5336 (Table 6).

\subsubsection{Diseases}

Diseases were generally low in incidence, or, the actual causal agent was not or could not be confirmed. Soybean downy mildew, Peronospora manshurica (Naoum) Syd., is a common fungal leaf disease of soybean that occurs when weather conditions are rainy and humid, as they were at Whitethorne in 2018. The proportion of leaves exhibiting fungal infection (characteristic yellow spots or lesions on leaves) was recorded in early September at peak infection. There was a highly significant effect of genotype on the percentage of leaves with downy mildew symptoms (Table 1); UA-Kirksey exhibited 100\% infected leaves, likely due to lack of adaptation specifically to the mid-Atlantic region (Table 7). Meanwhile, V16-0524 had 50\% infected leaves, and the remaining genotypes had little or no infection.

Table 7. Disease assessments comparing edamame genotypes and the commercial standard variety UA-Kirksey from trials conducted in Whitethorne (2018) and Painter (2019) in Virginia.

\begin{tabular}{cccc}
\hline & $\begin{array}{c}\text { Downy Mildew } \\
\text { Incidence }\end{array}$ & Bacterial Blight Severity & Incidence of Diseased Pods \\
\cline { 2 - 4 } & Whitethorne, VA, 2018 & Painter, VA, 2019 & Painter, VA, 2019 \\
\hline Genotype & (\% infected leaves) & (\% leaf area infected) & (\% unmarketable pods) \\
\hline R07-589 & $0.0 \pm 0.0 \mathrm{c}$ & $41.0 \pm 18.9 \mathrm{a}$ & $10.5 \pm 3.3 \mathrm{bc}$ \\
R14-6238 & $2.5 \pm 4.2 \mathrm{a}$ & $16.0 \pm 19.6 \mathrm{ab}$ & $12.3 \pm 4.0 \mathrm{bc}$ \\
R14-6450 & $10.0 \pm 9.0 \mathrm{c}$ & $14.0 \pm 6.2 \mathrm{ab}$ & $12.8 \pm 5.6 \mathrm{bc}$ \\
R14-16195 & $0.0 \pm 0.0 \mathrm{c}$ & $0.8 \pm 1.5 \mathrm{~b}$ & $5.8 \pm 1.3 \mathrm{c}$ \\
R15-10280 & $15.0 \pm 10.7 \mathrm{c}$ & $24.0 \pm 18.0 \mathrm{ab}$ & $28.3 \pm 3.9 \mathrm{a}$ \\
R16-5336 & $0.0 \pm 0.0 \mathrm{c}$ & $25.5 \pm 15.5 \mathrm{ab}$ & $15.5 \pm 5.3 \mathrm{bc}$ \\
UA-Kirksey & $100.0 \pm 0.0 \mathrm{a}$ & $22.0 \pm 11.9 \mathrm{ab}$ & $17.0 \pm 8.3 \mathrm{abc}$ \\
V10-3653 & $0.0 \pm 0.0 \mathrm{c}$ & $20.8 \pm 12.2 \mathrm{ab}$ & $14.5 \pm 4.7 \mathrm{bc}$ \\
V16-0524 & $52.5 \pm 13.7 \mathrm{~b}$ & $19.5 \pm 22.5 \mathrm{ab}$ & $22.0 \pm 8.3 \mathrm{ab}$ \\
V16-0528 & $0.0 \pm 0.0 \mathrm{c}$ & $2.0 \pm 4.0 \mathrm{~b}$ & $8.8 \pm 5.6 \mathrm{c}$ \\
V16-0547 & $0.0 \pm 0.0 \mathrm{c}$ & $27.8 \pm 20.8 \mathrm{ab}$ & $11.8 \pm 6.2 \mathrm{bc}$ \\
\hline
\end{tabular}

${ }^{1}$ Only data where the insect pest occurred in significant numbers are shown in the table. Numbers within a column followed by the same letter are not significantly different according to Fisher's LSD at $\mathrm{p}<0.05$. 
Bacterial blight, caused by Pseudomonas syringae Van Hall pv. glycinea, was present at the Painter trial in 2019 in moderate levels on edamame foliage. Infection severity of the genotypes can be seen in Table 6. R07-589 (41.0 \pm 18.9 ) showcased considerably higher infection severity than UA-Kirksey $(22.0 \pm 11.9)$, while genotypes R14-6450 (14.0 \pm 6.2$)$ and V16-0528 (2.0 \pm 4.0$)$ showed considerably less.

In 2019 at the Painter trial, a random sample of 50 pods/plot was assessed for being marketable or unmarketable (mostly due to disease lesions, insect lesions, or complexes between the two). Similar to bacterial blight ratings, R14-6450 (12.8 \pm 5.6$)$ and V16-0528 (8.8 \pm 5.6$)$ showed a lower percentage of unmarketable pods than UA-Kirksey (17.0 \pm 8.3$)$, while R15-10280 (28.3 \pm 3.9$)$ showed a higher percentage of unmarketable pods (Table 7).

\section{Discussion}

Edamame variety trials have been conducted in the U.S. since edamame first began to be nationally recognized [29] [30] [31] [32]. Many of these trials focused on varieties developed and imported from China, Japan, and Korea, as these varieties already contained the eating quality and pod characteristics valued by traditional consumers of edamame [6] [10]. As a consequence of poor local adaptation, however, these varieties tend to yield poorly in mid-southern and southeastern production regions. A recently conducted a study by Jiang et al. characterized 86 food-grade soybean breeding lines for commercial edamame production in Virginia, and found numerous genotypes that appeared to show high yield potential [33]. These findings suggested that utilization of food-grade soybean genotypes already bred to local climatic conditions in the region may present a more immediate remedy for the poor agronomic performance of currently available edamame varieties.

Results from our study corroborated results from Jiang et al., as many of the food-grade genotypes in this study from both Arkansas and Virginia appeared on-par with or better than the commercial check. For example, only half of the prospective edamame genotypes observed in this present study showed significantly lower yield potential than UA-Kirksey. Of the remaining five genotypes, three failed to show statistically significant differences in yield with UA-Kirksey and the other two showed even higher yield potential. In addition, many of the food-grade soybean genotypes in our study showed pod characteristics that were comparable to the commercial check. At least half of the genotypes matched or showed significantly higher pod length than UA Kirksey, while four genotypes showed comparable 10-pod weight. A wide range of pubescence densities was also observed among the genotypes with several showing lower pubescence densities than UA Kirksey which is favorable for its processability.

Studies on heritability of soybean pod characteristics are scarce in the literature, especially at the R6 stage. In the study conducted by Jiang et al., high broadsense heritability was observed for 100 -seed weight of both fresh and dry seeds. 
Our study only focused on fresh pods and beans. The high broad-sense heritability for fresh pod yield $\left(\mathrm{H}^{2}=0.82\right)$ and pod length $\left(\mathrm{H}^{2}=0.92\right)$ observed in this study closely mirrors findings from Mebrahtu \& Mohamed [12] who observed similarly high broad-sense heritability estimates for these same traits. We also observed relatively high broad-sense heritability estimates for other traits such as 10 -pod weight (0.73) and proportion of one-bean pods (0.86), which to our knowledge have not yet been reported in the literature. The high broad-sense heritability estimates observed across agronomic traits here suggest that environmental effects did not appear to considerably impact pod weight, pod dimension traits or one-bean pod proportion. As such, these traits may be ideal breeding targets to develop commercial varieties and germplasm that more closely resemble traditional edamame and thus may benefit from increased consumer acceptance.

Two genotypes in our study, V16-0524 and R15-10280, outperformed the commercial check UA-Kirksey in several key categories. Firstly, both genotypes showed consistently high yield and notably stronger adaptation, resistance to local disease and insect pest pressures, and comparable pod characteristics to the commercial check variety. V16-0524 also showed one of the lower one-bean pod proportions observed in the study and had substantially less downy mildew and stink bug damage than the commercial check. Despite its numerous agronomic advantages, however, V16-0524 had one of the shorter pod lengths observed in this study; whereas, R15-10280 showed ideal pod dimensions that closely mirrored the commercial check and even outperformed it for ten pod weight as well as downy mildew damage. Both R15-10280 and V16-0524 showed appreciably lower pubescence densities than the other genotypes in the study, including the commercial check, which is critical for consumer appeal and drying time in fresh packing operations.

Given the dynamic nature of pests from year to year, continued studies on native pest pressures, economic thresholds, and management strategies are needed to further facilitate adoption of edamame in the state. In addition, determining the mechanical or physiological resistance mechanisms that resulted in differences in pest pressure or injury among the genotypes will help guide future plant breeding endeavors.

\section{Conclusion}

The strong agronomic performance of the genotypes in this study relative to the commercial check demonstrates how food-grade soybean genotypes can be leveraged as a useful genetic resource for edamame variety development. In addition, the high broad-sense heritability estimates for yield and pod characteristics observed here suggest that there is strong potential to improve edamame product marketability through breeding selection. Two genotypes from our study, V16-0524 and R15-10280, can be immediately used to provide growers in the region with superior, commercially-viable seed inputs with strong yield potential 
and local pest tolerance.

\section{Acknowledgements}

The authors thank USDA-NIFA and Virginia Agricultural Council for financial support. The authors also thank Jill Pollok, James Jenrette, Daniel Wilczek, Brian Currin, Katlyn Catron, Kadie Britt, Mika Pagani, Sean Boyle, Andy Dechaine, and Kyle Bekelja, Jim Jenrette, and Muliang Peng for help with field plot maintenance and data collection, and Leandro Mozzoni for providing seeds of edamame breeding lines.

\section{Conflicts of Interest}

The authors declare that the research was conducted in the absence of any commercial or financial relationships that could be construed as a potential conflict of interest.

\section{Authors' Contributions}

Nilanka (Nick) Lord and Thomas Kuhar were the primary authors of the paper. All other co-authors contributed to the research presented and edited previous drafts of the manuscript.

\section{Funding}

This research was supported by the USDA-NIFA, Grant No. 2018-51181-28384, Accession No. 1016465, and the Virginia Agricultural Experiment Station.

\section{References}

[1] Shurtleff, W. and Aoyagi, A. (2014) History of Edamame, Green Vegetable Soybeans, and Vegetable-Type Soybeans (1275-2009): Extensively Annotated Bibliography and Sourcebook. Soyinfo Center, Lafayette. https://www.soyinfocenter.com

[2] Shurtleff, W., Huang, H. and Aoyagi, A. (2014) History of Soybeans and Soyfoods in China and Taiwan, and in Chinese Cookbooks, Restaurants, and Chinese Work with Soyfoods outside China (1024 BCE to 2014): Extensively Annotated Bibliography and Sourcebook, Including Manchuria, Hong Kong and Tibet. Soyinfo Center, Lafayette. https://www.soyinfocenter.com

[3] Born, H. (2006) Edamame: Vegetable Soybean. A Publication of ATTRA-National Sustainable Agriculture Information Service. https://www.attra.ncat.org

[4] Mentreddy, S.R., Mohamed, A.I., Joshee, N. and Yadav, A.K. (2002) Edamame: A Nutritious Vegetable Crop. In: Janick, J. and Whipkey, A., Eds., Trends in New Crops and New Uses, ASHS Press, Alexandria, 432-438.

[5] Masuda, R. and Harada, K. (2000) Carbohydrate Accumulation in Developing Soybean Seeds; Sucrose and Starch Levels in 30 Cultivars for Soyfoods. The Third International Soybean Processing and Utilization Conferences: Japanese Food Science and Technology, Tsukuba, 15-20 October 2000, 15-20.

[6] Young, G., Mebrahtu, T. and Johnson, J. (2000) Acceptability of Green Soybeans as a Vegetable Entity. Plant Foods for Human Nutrition, 55, 323-333.

https://doi.org/10.1023/A:1008164925103 
[7] Ruiz-Larrea, M.B., Mohan, A.R., Paganga, G., Miller, N.J., Bolwell, G.P. and RiceEvans, C.A. (1997) Antioxidant Activity of Phytoestrogenic Isoflavones. Free Radical Research, 26, 63-70. https://doi.org/10.3109/10715769709097785

[8] Sarkar, F.H. and Li, Y. (2002) Mechanisms of Cancer Chemoprevention by Soy Isoflavone Genistein. Cancer and Metastasis Reviews, 21, 265-280. https://doi.org/10.1023/A:1021210910821

[9] Taku, K., Umegaki, K., Sato, Y., Taki, Y., Endoh, K. and Watanabe, S. (2007) Soy Isoflavones Lower Serum Total and LDL Cholesterol in Humans: A Meta-Analysis of 11 Randomized Controlled Trials. The American Journal of Clinical Nutrition, 85, 1148-1156. https://doi.org/10.1093/ajcn/85.4.1148

[10] Rao, M., Bhagsari, A.S. and Mohamed, A.I. (2002) Fresh Green Seed Yield and Seed Nutritional Traits of Vegetable Soybean Genotypes. Crop Science, 42, 1950-1958. https://doi.org/10.2135/cropsci2002.1950

[11] Garber, B. and Neill, C.L. (2019) Edamame: Costs, Revenues, and Profitability. Virginia Cooperative Extension Publications No. AAEC-189P.

[12] Mebrahtu, T. and Mohamed, A. (2006) Genetic Variation for Green Pod Yield and Quality among Vegetable Soybean Genotypes. Journal of Crop Improvement, 16, 113-130. https://doi.org/10.1300/J411v16n01 08

[13] Mozzoni, L. and Chen, P. (2019) Correlations of Yield and Quality Traits between Immature and Mature Seed Stages of Edamame Soybean. Journal of Crop Improvement, 33, 67-82. https://doi.org/10.1080/15427528.2018.1542366

[14] Zhang, Q.Y., Hashemi, M., Hebert, S.J. and Li, Y.S. (2013) Different Responses of Preemergence and Early Seedling Growth to Planting Depth between Vegetable Soybean and Grain Soybeans. Legume Research, 36, 515-521.

[15] Masuda, R. (1991) Quality Requirement and Improvement of Vegetable Soybean. Proceedings of the Asian Vegetable Research and Development Center Workshop, Kenting, 29 April-2 May 1991, 92-102.

[16] Cui, Z., James, A., Miyazaki, S., Wilson, R.F. and Carter, T. (2004) Breeding Specialty Soybeans for Traditional and New Soyfoods. In: Liu, K., Ed., Soybeans as a Functional Food. AOCS Press, Champaign, Illinois, 264-322.

[17] Konovsky, J., Lumpkin, T.A. and McClary, D. (1994) Chapter 15: Edamame: The Vegetable Soybean. In: O’Rourke, A.D., Ed., Understanding the Japanese Food and Agrimarket: A Multifaceted Opportunity, Taylor and Francis Group, London, 173 181. https://doi.org/10.1201/9781003075172-15

[18] Wszelaki, A.L., Delwiche, J.F., Walker, S.D., Liggett, R.E., Miller, S.A. and Kleinhenz, M.D. (2005) Consumer Liking and Descriptive Analysis of Six Varieties of Organically Grown Edamame-Type Soybean. Food Quality and Preference, 16, 651-658. https://doi.org/10.1016/j.foodqual.2005.02.001

[19] Wilcox, J.R. and Shibles, R.M. (2001) Interrelationships among Seed Quality Attributes in Soybean. Crop Science, 41, 11-14. https://doi.org/10.2135/cropsci2001.41111x

[20] Carneiro, R.C.V., Duncan, S.E., O’Keefe, S.F., Yin, Y., Neill, C.L. and Zhang, B. (2020) Sensory and Consumer Studies in Plant Breeding: A Guidance for Edamame Development in the U.S. Frontiers in Sustainable Food Systems, 4, 124. https://doi.org/10.3389/fsufs.2020.00124

[21] Chen, P., Scaboo, A.M., Dombek, D.G. and Robbins, R.T. (2014) Soybean Cultivar UA Kirksey. U.S. Patent No. US20140026250A1. U.S. Patent and Trademark Office, Washington DC.

[22] Fehr, W.R., Caviness, C.E., Burmood, D.T. and Pennington, J.S. (1971) Stage of 
Development Descriptions for Soybeans, Glycine-max (L.) Merrill. Crop Science, 11, 929. https://doi.org/10.2135/cropsci1971.0011183X001100060051x

[23] Carlson, J.B. and Lersten, N.R. (2004) Reproductive Morphology. In: Soybeans: Improvement, Production, and Uses, Agronomy Monograph No. 16, American Society of Agronomy, Madison, 59-95. https://doi.org/10.2134/agronmonogr16.3ed.c3

[24] Kuhar, T.P., Hoffmann, M.P., Stivers-Young, L.J., Marini, M. and Sterrett, S.B. (2003) Potato Leafhopper Economic Injury Levels on Early-Stage Snap and Kidney Beans. HortTechnology, 13, 647-649. https://doi.org/10.21273/HORTTECH.13.4.0647

[25] Kuhar, T.P., Doughty, H. and Jenrette, J. (2015) Evaluation of Insecticides for the Control of Pod-Damaging Insects in Snap Beans in Virginia, 2014. Arthropod Management Tests, 40, E11. https://doi.org/10.1093/amt/tsv067

[26] Nottingham, L.B. and Kuhar, T.P. (2016) Natural History, Ecology and Management of Mexican Bean Beetle on Bean Crops in the U.S. Journal of Integrated Pest Management, 7, 1-12. https://doi.org/10.1093/jipm/pmv023

[27] Owens, D.R., Herbert, D.A., Dively, G.P., Reisig, D.R. and Kuhar, T.P. (2013) Does Feeding by Halyomorpha halys Stål (Hemiptera: Pentatomidae) Reduce Soybean Seed Quality and Yield? Journal of Economic Entomology, 106, 1317-1323. https://doi.org/10.1603/EC12488

[28] Venette, R.C. and Ragsdale, D.W. (2004) Assessing the Invasion by Soybean Aphid (Homoptera Aphididae). Annals of the Entomological Society of America, 97, 219 226. https://doi.org/10.1093/aesa/97.2.219

[29] Delate, K., Friedrich, H., Burcham, R., Fehr, W.R. and Wilson, L.A. (2003) Edamame (Vegetable Soybean) Variety Trial at Neely-Kinyon Farm, 2002. Iowa State University Research and Demonstration Farms Progress Reports, 3. https://doi.org/10.31274/farmprogressreports-180814-828

[30] Nolen, S., Zhang, B. and Kering, M. (2016) Increasing Fresh Edamame Bean Supply through Season Extension Techniques. Journal of Horticulture, 3, 1-5. https://doi.org/10.4172/2376-0354.1000170

[31] Sharma, K.P. and Kshattry, I. (2013) Varietal Adaptation Study to Initiate Edamame Production in Richmond, BC. Nature's Path Foods, Richmond, 29 p.

[32] Zhang, L. and Kyei-Boahen, S. (2007) Growth and Yield of Vegetable Soybean (Edamame) in Mississippi. HortTechnology, 17, 26-31. https://doi.org/10.21273/HORTTECH.17.1.26

[33] Jiang, G.L., Rutto, L.K. and Ren, X.S. (2018) Evaluation of Soybean Lines for Edamame Yield Traits and Trait Genetic Correlation. Hortscience, 53, 1732-1736. https://doi.org/10.21273/HORTSCI13448-18 